Easy to chew, but hard to swallow - consumer perception of neutrally marinated meat

Nissen, Nina Konstantin; Sandøe, Peter; Holm, Lotte

Published in:

British Food Journal

DOI:

$10.1108 / 00070701211252075$

Publication date:

2012

Document version

Peer reviewed version

Citation for published version (APA):

Nissen, N. K., Sandøe, P., \& Holm, L. (2012). Easy to chew, but hard to swallow - consumer perception of neutrally marinated meat. British Food Journal, 114(8), 1095-1105. https://doi.org/10.1108/00070701211252075 


\title{
Easy to chew, but hard to swallow - consumer perception of neutrally marinated meat $^{1}$
}

\author{
Nina Konstantin Nissen ${ }^{\S}$ \\ Peter Sandøe \\ Lotte Holm ${ }^{\S}$
}

$\S$ Institute of Human Nutrition and Institute of Food and Resource Economics, University of Copenhagen, Copenhagen, Denmark

\# Danish Centre for Bioethics and Risk Assessment, University of Copenhagen,

Copenhagen, Denmark

\begin{abstract}
Background: Meat which has been injected or tumbled with water, salt, sugar and other ingredients, has been available on the Danish market for some decades and is now becoming increasingly common. However, it is not known whether this so-called neutrally marinated meat will be appropriated by consumers in the long term, or will be destined to be a marginal second rate product.
\end{abstract}

Purpose: To explore the views of consumers on neutrally marinated meat, including acceptance and potential problems for appropriation.

Design: Four focus group interviews were conducted involving 27 Danish consumers with various socio-demographic backgrounds.

Findings: The interviewed consumers had very little prior knowledge of neutrally marinated meat, and expressed ambivalent attitudes when introduced to it. They had favourable reactions to its taste, texture and robustness and saw the potentially low price as a positive feature. But they also viewed neutrally marinated meat as unnatural, unauthentic and potentially risky to health. Furthermore, concern was expressed due to the lack of information available to consumers and due to suspicion of unfair prices. The focus group interviews also showed that categorisation of neutrally marinated meat in different social contexts is not settled, underlining a sense of ambivalence among consumers. So, even though neutrally marinated meat is being consumed it is unclear if and when conceptual appropriation will take place.

Originality: This study provides a broader perspective on consumer perception of new products than found in conventional sensorial tests, including views on the processing, health aspects, ethical aspects and convenience aspects.

Keywords: Neutrally marinated meat, enhanced meat, consumers, focus group interviews, appropriation.

\footnotetext{
${ }^{1}$ This is the authors' postprint version of: Nissen NK, Sandøe P \& Holm L (2012): Easy to chew, but hard to swallow - consumer perception of neutrally marinated meat. British Food J ournal 114 (8): 1095-1105. http://dx.doi.org/10.1108/00070701211252075
} 


\section{Introduction}

This paper presents a case study of potential problems for the appropriation of new food products. The case study concerns a relatively new type of meat product, socalled neutrally marinated meat, which is meat injected or tumbled with water, salt, sugar and other ingredients such as phosphates, antioxidants and acids. The aim of neutral marination is to make the meat more juicy and tender, and some of the ingredients prevent rancidness and the growth of bacteria (Danish Meat Association, 2006; Dörffer, 2003; Hayes et al., 2006; Pietrasik and Shand, 2011). Neutrally marinated meat represents a technological novelty on the meat market, which is becoming increasingly common in industrialised countries all over the world. Unlike other innovations it has not been marketed as such, and in general, the introduction and spread of neutrally marinated meat have gone rather unnoticed.

When a new group of food products like this one enters the market, its viability and future position on the market depend on consumers' acceptance and appropriation. Consumers' acceptance of food products depends on their experience of the taste and appearance of the products, but also on a number of other factors, such as the origin and processing of products (Holm and Kildevang, 1996; Holm and Møhl 2000), nutritional content (sugar, fat etc.) and health aspects (Korzen-Bohr and O'Doherty Jensen, 2006), ethical aspects such as animal welfare, and convenience aspects (Bruhn, 2008). For new products to remain on the market, it is necessary that they are not only accepted, but also appropriated by consumers.

Appropriation means that new products become familiar and that consumers make them 'their own' in both a practical and conceptual manner (Miller, 1987; Niva, 2008). For new food products, this implies that they go through a process of integration into existing eating patterns. Part of this process involves the products finding a place in the relevant culinary systems and taxonomies, and becoming located in existing culinary categories, defining the products' place in the meal system (e.g. as breakfast or dinner) and their status relative to other products (e.g. as low or high status food). There are several examples in history of technologically advanced products, which have met severe problems of appropriation. For example, UHT milk and instant coffee have been introduced on the Danish market but have never become accepted as proper quality products by consumers.

Studies have investigated consumers' sensorial assessments of neutrally marinated meat through blind tests (Carr et al., 2004; ; Hayes et al., 2006; Pietrasik and Shand, 2011Robbins et al., 2003; Søndergaard, 2007), but our literature search showed no studies with a broader perspective on consumers' acceptance of neutrally marinated meat. We therefore set out to conduct a study which focuses on exploring the full range of views of consumers regarding neutrally marinated meat, using Danish consumers as a case.

In this paper, we first describe neutrally marinated meat and its position on the Danish market. We then present the methodology of the study, followed by the results about peoples' views on neutrally marinated meat. Finally, we discuss some of the major problems related to the manner in which this new technology has been introduced in Denmark and conclude with outlining possible outcomes from the Danish case.

\section{Neutrally marinated meat in Denmark}

In Denmark, the method of injecting or tumbling meat with water, salt, sugar and other ingredients is called 'neutralmarinering' which literally translates into 'neutral marination', and meat processed in this way is called 'neutralmarineret kød'. In this paper, we do not use the common English terms 'plumbed' or 'enhanced', but stick to the terms 'neutrally marinated meat' and 'neutral marination', because they are more in line with the Danish terms used by the informants in our study. 
According to reports from media and the meat industry a noticeable portion of the pork, beef and especially poultry either produced in or imported into Denmark has been neutrally marinated and the weight of the meat has typically been increased by $5-15 \%$. In wholesale, neutrally marinated pork, beef and poultry is common, whereas in retail, it is mostly poultry that is neutrally marinated (Danish Meat Association, 2006; Dörffer, 2003).

The introduction and spread of neutrally marinated meat in Denmark has occurred during the latest decades, but has gone rather unnoticed. However, some criticism has been raised in the media and in the Danish Parliament about this method of processing meat and the way it is marketed (Folketingets Lovsekretariat, 2006; 2007; Hvilsom, 2006; Jydske Vestkysten, 2005). In 2010, the Danish Parliament unanimously adopted a law comprising strict rules on the production and naming of neutrally marinated meat (Guldagger, 2010).

The meat industry, consumer organisations and universities have carried out sensorial tests to discover how sensorial experts and lay people assess the taste and texture of neutrally marinated meat, compared to meat that has not been processed (e.g. Hayes et al., 2006; Pietrasik and Shand, 2011; Søndergaard, 2007; Tørngren, 2007). Generally, in these tests the neutrally marinated meat is favoured (Hayes et al., 2006; Pietrasik and Shand, 2011; Søndergaard, 2007; Tørngren, 2007). To our knowledge, the views of ordinary consumers have not been represented in the public debate, and their views on the notion of neutrally marinated meat have not been investigated scientifically. Therefore, until the present study was conducted we did not know much about the views of consumers concerning neutrally marinated meat besides their immediate opinions on taste and texture.

\section{Methods}

The study is based on qualitative, semi-structured focus group interviews. In September 2008, four focus group interviews were conducted with 5-8 participants in each group $(\mathrm{N}=27)$. Participants were recruited by a market analysis company using a random telephone generator among their participant panel. Two of the focus group interviews took place in a rural area, while the other two took place in Copenhagen. To ensure variation in the views and arguments, each group was varied regarding age, gender, family type and educational background. Inclusion criteria were: over 18 years of age; not living with parents, shared or sole responsibility for food shopping in the household, no professional occupation within the food sector, no vegetarianism and no higher university education. Participants received gift vouchers for a variety of shops (value approx $£ 30$ ) in return for the contributions.

The focus group interviews were organised around joint tasks (see Table 1), which encouraged the participants to express their views on various aspects of neutrally marinated meat and to discuss contradicting views in the groups. The interviews lasted for approximately $\mathbf{1 5 0}$ minutes each and were moderated by the first author of this paper.

Table 1: Main points in guide for focus group interviews

\begin{tabular}{|l|l|}
\hline Section/ task & Description \\
\hline Introduction & $\begin{array}{l}\text { Presentation of moderator and assistant. Introduction to the interview and } \\
\text { expectations of participants. }\end{array}$ \\
\hline $\begin{array}{l}\text { Presentation of } \\
\text { participants }\end{array}$ & $\begin{array}{l}\text { Participants were asked to introduce themselves, their backgrounds, } \\
\text { households, and aspects of their ordinary eating. }\end{array}$ \\
\hline Ranking of meat & $\begin{array}{l}\text { Participants were asked to rank ten cards with photos and names of } \\
\text { different meat products as better or worse according to their views on } \\
\text { meat quality. }\end{array}$ \\
\hline
\end{tabular}




\begin{tabular}{|l|l|}
\hline Associations & $\begin{array}{l}\text { Discussion on the basis of participants' notes of their spontaneous } \\
\text { associations with the words 'neutrally marinated'. }\end{array}$ \\
\hline $\begin{array}{l}\text { The technology of } \\
\text { neutral marination }\end{array}$ & $\begin{array}{l}\text { Interviewer gave a short description of neutrally marinated meat and the } \\
\text { way it is produced. On this basis, a group discussion took place and four } \\
\text { additional cards with different types of neutrally marinated meat were } \\
\text { placed in the ranking of better and worse meat already made. }\end{array}$ \\
\hline $\begin{array}{l}\text { Tastings of } \\
\text { neutrally } \\
\text { marinated meat }\end{array}$ & $\begin{array}{l}\text { Participants were served taste samples of neutrally marinated meat versus } \\
\text { meat that had not been processed. All the meat was pork neck fried as } \\
\text { cutlets on an ordinary frying-pan up to 75 degrees Celsius. The neutrally } \\
\text { marinated meat had been injected with a solution of water, salt, sugar and } \\
\text { additives. }\end{array}$ \\
\hline $\begin{array}{l}\text { Neutrally } \\
\text { marinated meat in } \\
\text { social contexts }\end{array}$ & $\begin{array}{l}\text { Participants sorted ten cards describing different social situations in two } \\
\text { groups according to whether or not they would like to serve or be served } \\
\text { neutrally marinated meat in these situations. }\end{array}$ \\
\hline $\begin{array}{l}\text { Opinions of } \\
\text { stakeholders }\end{array}$ & $\begin{array}{l}\text { Eleven cards describing different stakeholders were sorted according to } \\
\text { whether or not neutral marination was considered beneficial to the } \\
\text { stakeholders or not, and the participants were encouraged to discuss } \\
\text { neutrally marinated meat in this context. }\end{array}$ \\
\hline Closing & \begin{tabular}{l} 
Additional comments, evaluation of interview. \\
\hline
\end{tabular}
\end{tabular}

All interviews were recorded and transcribed verbatim. The approach taken to data coding and analysis was based on ethnographic analysis and template analysis (Crabtree and Miller, 1999; Hammersley and Atkinson, 1995). Reading the transcripts of the first two focus group interviews resulted in the identification of themes and an initial code-system was developed. This code-system formed the basis for the careful reading of all the transcripts and the themes were developed further; themes being split up or put together, new themes coming and others taken out, and themes changing from being descriptive to more analytical. This codingprocess gave an overview of data and formed the basis for the analysis, which was done thematically.

\section{Results}

In general, the concept of neutral marination was unknown to the consumers that participated in the focus group interviews. Most of the interviewed consumers did not know that meat is being processed in this way and were surprised that neutrally marinated meat is sold in Danish supermarkets. The terms 'neutral marination' and 'neutrally marinated meat' were unfamiliar to most of the interviewees. Some did recognise the words from labels in supermarkets or from the media, but did not know what they meant. Consequently, most interviewees reported that, as far as they knew, they had never tasted neutrally marinated meat. Only a few reported personal experiences with buying, cooking and/or eating neutrally marinated meat, and in all cases this had happened by accident and not on purpose.

When being introduced to the concept of neutral marination, the interviewed consumers' immediate reactions were predominantly negative. Their first comments included words like "ugh", "suspicious" and "totally meaningless". But as the discussion proceeded and the interviewees tasted the meat, complex and ambivalent views showed. Each interviewee typically expressed views both in favour and against neutral marination.

Favourable views supporting interviewees' acceptance of neutrally marinated meat

Positive comments revolved around the taste and texture of neutrally marinated 
meat, the cooking quality of the meat and the anticipated price of neutrally marinated meat products.

Spontaneously, the interviewees assumed that neutrally marinated meat would be either tasteless or taste worse than unprocessed meat. However, after having tasted and compared neutrally marinated pork to unprocessed pork during the focus group interviews, most interviewees changed their ideas about the taste as they found the neutrally marinated pork more flavoursome. Even though a few interviewees stated that they found the taste or flavour artificial, in general, the interviewees liked the taste of neutrally marinated meat very much.

Birthe was one of those interviewees who, from the outset, was very critical but - to her surprise - liked the neutrally marinated meat very much. She said:

"Actually, it tastes better... [...] I must admit that I think it tasted very good"

Particular expectations regarding the texture of the neutrally marinated meat were not stated by the interviewees before the tastings, but subsequent to tasting, tenderness was often mentioned as an important characteristic with regard to the quality of the meat.

A few interviewees found the tenderness and juiciness to be 'too much', disproportionate or artificial, but most interviewees were amazed and positive about this and stated that they liked the fact that the meat was easier to chew and cut. Lone, a female interviewee in one of the focus group interviews said while she was chewing:

"Actually I like the marinated one best. I like the fact that it is not as dry as the other one and that it is not so tough to cut"

During the focus group interviews, participants were informed that neutrally marinated meat remains tender and juicy, even if it is fried for too long or warmedup several times. Many saw this as an important advantage. They emphasised that people with poor cooking skills may benefit from choosing neutrally marinated meat and welcomed the fact that neutrally marinated meat makes it easier for anyone to cook meat properly; that is to say to produce meat that is juicy and tender and with a good taste. They liked the thought of not having to be so careful when cooking, and of being more certain of a successful outcome, especially when serving food for guests. A female interviewee, Betina, said:

"Neutrally marinated meat is totally free from the risk of failure, compared to fresh meat"

On the other hand, some of the interviewed consumers had reservations about the advantages of cooking neutrally marinated meat, as they expected most people to be able to cook good meals, also when using unprocessed meat. To accommodate poor cooks was seen as taking the wrong path. Rather, such persons should learn the skill. Moreover, some interviewees reported that they much preferred to prepare their food from scratch themselves, even when this is not the most convenient method. They preferred meat that had undergone a minimum of industrial processing, and they found it easier to control the freshness and quality of meat that had not been processed by the industry.

Some interviewees were positive about the fact that they expected neutrally marinated meat to be cheaper than other meat. They assumed that the cost of production is lower for neutrally marinated meat, because water is added and poorer 
cuts of meat can be used. A male interviewee, Troels, said:

"I have this idea that when you make a product of poor quality, you put down the price proportionally"

Some interviewees stated that they, or someone they knew, would prefer neutrally marinated meat to other meat products if it was cheaper, because price is an important consideration when choosing meat. A female interviewee, Eva, said:

"If it is cheaper per kilogram to buy the neutrally marinated, that would be an advantage for persons with little money"

Unfavourable views impeding interviewees' acceptance of neutrally marinated meat

Negative comments revolved around perceived health risks, unnaturalness of the products, and the misleading character of the product names.

In the focus group interviews, much attention was given by participants to the potential health risks perceived to be associated with eating neutrally marinated meat. This topic caused speculation and some concern. Unspecific connections between the consumption of neutrally marinated meat and risks of specific diseases such as cancer, diabetes and allergies were anticipated. Furthermore, many expected other long-term, but yet unknown risks to be likely. Betina expressed her worries this way:

"I am worried what marinating may do to us in 30 years time. What problems will there be in the health area? How will it affect us? Will it raise the risk of cancer? What discomfort will it cause? What complications will it cause?"

The interviewees were especially concerned about the health risks that susceptible people may be exposed to when eating neutrally marinated meat. They were worried about children and about people who already suffer from health problems, especially cancer patients, kidney patients, people with allergies, and elderly people, who in general have poor health. Some interviewees also worried that those who eat neutrally marinated meat might run the risk of protein deficiency. By contrast, the interviewees rarely expressed concerns about the more immediate and direct risk of diseases caused by bacteria that has been drawn attention to by the meat industry (Danish Meat Association, 2006; Dörffer, 2002).

A few interviewees pointed out potential health advantages of eating neutrally marinated meat, as it would imply a decrease in the intake of meat and an increase in the intake of water and thus potentially have a slimming effect. They also suggested that some elderly people might avoid weight loss since it is easier for them to chew neutrally marinated meat enabling them to eat more. However, compared to the expected health risks, the suggested health advantages only played a small part in the discussions.

The anticipated health risks seemed to be linked to an understanding of neutrally marinated meat as being unnatural and unauthentic. When the interviewed consumers spoke about neutrally marinated meat they used words such as "false", "synthetic" and "alarming", whereas fresh meat was referred to as "real", "pure", "authentic" and "natural". The interviewees emphasised that they preferred to know how the meat they eat has been processed and who has done it. Meat that has not been industrially processed was viewed as being safer because it is as basic and untouched as possible. Further, the views about neutrally marinated meat being 
unnatural and unauthentic also seemed to be an expression of the interviewees' feelings of the loss of the quality and cultural values that are linked to food that has been through only a minimum of processing and that has a known history.

Additionally, many interviewees were sceptical about neutrally marinated meat since they felt cheated because of the misleading term "neutrally marinated" and the lack of information about how the meat is being processed. All interviewees found that the expression, 'neutrally marinated' was a contradiction in terms and misleading. Their associations with the word were negative. A male interviewee, Karsten, said:

"It smells of camouflage. [...] if the label said 'pumped-up with water' it would after all have been more honest than 'neutrally marinated'. 'Pumped-up with water' would be a better description"

The interviewees also felt deceived, because they had not been informed of what neutrally marinated meat was or the fact that a lot of the meat sold in Denmark is processed in this way. A female interviewee, Karin, stated:

"Nothing has been done to point out the difference [between unprocessed meat and neutrally marinated meat]. And that makes me angry, because I feel very much cheated as a consumer. I think it is a disgrace to cheat me in this way"

Furthermore, some interviewees felt deceived because they assumed the price of neutrally marinated meat to be high, and they did not like the thought of "paying for water". They suspected that producers and retailers would impose surcharges and increase their profit on neutrally marinated meat, despite the consequences for consumers with regard to cost, health, etc. The interviewees were upset about this and felt that they were being forced to pay for more than they got, especially since it had not been clear to them that the meat they were buying was neutrally marinated.

Neutrally marinated meat in different social contexts

The focus group interviews demonstrated that neutrally marinated meat is viewed differently depending on whether the meat is part of special, festive occasions or everyday meals.

At first, many interviewees reported they would be reluctant to accept neutrally marinated meat when eating out, serving food for guests or on other special, festive occasions. On such occasions, food was expected to be made from scratch from basic materials of good quality, and neutrally marinated meat did not fit this picture. Neutrally marinated meat did not fit well with the interviewees' ideas of good cooking. A female interviewee, Lisbeth, said:

Cooking is one of my main hobbies, and my husband's too. I would never dream of... really! The fine art is precisely to get the perfect out of what you have got"

However, some interviewees viewed it more positively because it could increase the likelihood of a successful outcome of their cooking endeavours - i.e. that the meat would be juicy and tender. In their view, this would motivate private consumers, as well as good restaurants, to use neutrally marinated meat when serving food at special occasions. 
A female interviewee, Ingrid, saw the use of marinated meat as a chance for her to avoid failures in the kitchen:

"if I am going to have guests, I will go for the neutrally marinated roast. Then they would praise my cooking"

Generally, interviewees were more open to the idea of neutrally marinated meat with regard to ordinary, everyday meals, whether cooked at home or eaten in cheap restaurants, or the like. In line with this, most interviewees accepted the use of neutrally marinated meat in large kitchens that cater for many people, for instance in hospitals, nursing homes and work canteens. In everyday contexts and especially in large kitchens, neutrally marinated meat was deemed more appropriate because shortage of time and money were seen as basic constraints in these contexts. When commenting on buying every day meals in take-away outlets, Jakob said:

"We cannot expect such places to sell unprocessed meat, and we accept that, when we go to these places and buy things at that price, because we just want it to be fast"

Still, it must be maintained that even in everyday contexts, the acceptance of neutrally marinated meat was not unanimous. Some interviewees raised concerns about an assumed risk for dangerous ingredients mounting up in the body, if neutrally marinated meat was eaten on a daily basis.

\section{Discussion}

The focus group interviews indicated that consumers have very little knowledge about neutrally marinated meat. Most of the interviewed consumers did not know that meat is processed in this way and they did not know the terms used for labelling this kind of meat. None of the interviewees had chosen to buy, cook or eat neutrally marinated meat deliberately.

Despite this, strong opinions about neutrally marinated meat were expressed in the focus group interviews after the interviewees had been introduced to the concept of neutral marination. A clear ambivalence was displayed, between on the one hand, favourable views of the taste, texture, robustness and potentially low price of this kind of meat, and, on the other hand, views of the meat as being unnatural, unauthentic and potentially risky to health. Further, a sense of concern was widespread because of a lack of information, anticipated unfair prices, and a suspicion that the meat industry and retailers produce and sell neutrally marinated meat only for profit without any consideration of the consequences for consumers. Typically, the informants were split between their positive experiences when tasting neutrally marinated meat, and their critical views.

Further, neutrally marinated meat was perceived differently depending on the social context and it became clear that the categorisation of neutrally marinated meat in different social contexts is, as yet, unsettled. This conceptual indefiniteness may further the sense of ambivalence among consumers.

These results point to a double set of tensions which are not yet settled. The acceptance of some quality aspects of the products needs to be balanced with the rejection of the whole idea of the neutral marination of meat and the suspicion of cheating. Sociological studies show that the appropriation of foods often takes the shape of a complex web of new and old ideas and gradual shifts or adaptions in everyday practices concerning food, eating and related practices, which can be explored by an analytical distinction between practical and conceptual appropriation (Niva, 2008). In the case of neutrally marinated meat, practical appropriation 
appears to have taken place, as the interviewees were likely to already have bought and eaten such products without being aware of it. Conceptual appropriation appears to be further away, since neutrally marinated meat has not yet been settled in the food categorisation system, and it is not clearly associated with everyday and discount food or with festive occasions and gourmet food.

The consumers' reaction to neutrally marinated meat may be paralleled to the reactions to and the position of UHT milk on the Danish market. UHT milk, which has been heat-treated to a higher temperature than fresh milk and therefore has a longer storage life and can be stored at room temperature, was introduced on European markets in the early 1980's.

In numerous European countries, UHT milk quickly became popular, because it was cheap and easy to store. In Germany, $60 \%$ of consumers drink UHT milk and in France and Spain more than $90 \%$ of the drinking milk sold is UHT (Abildgaard, 2010; Haugaard, 2007).

In contrast, UHT milk has not become popular in Denmark. Only $1 \%$ of the milk sold on the Danish market is UHT, and new types of UHT milk (ESL milk), which recently has been introduced in other European countries, has not been put on the shelves in Danish stores, because the dairy producers expect it to be unsellable (Abildgaard, 2010). Still, Danish consumers do buy UHT products when it comes to chocolate milk and milk desserts. This position of UHT milk on the Danish market reflects problems with the conceptual appropriation. UHT milk differs from what Danish consumers associate with milk, because the taste is slightly different from fresh milk, it has a longer product life and it can be stored outside the refrigerator until opened, and these characteristics question the authenticity of UHT milk. On the other hand, consumers do not hesitate to buy this kind of milk when it has been made into chocolate milk and desserts. This might be because they are not to the same extent concerned with the quality of the milk in these products.

Thus, though there has been some practical appropriation, since consumers do buy products containing UHT milk, the conceptual appropriation of this kind of product is lacking. Other products have been met with the same ambivalence and lack of conceptual appropriation in Denmark. Examples are instant coffee and breaded chicken fingers. When entering the market, both products were originally seen as being modern and sophisticated convenience products. But after some time, their relative status in Danish food culture declined and they are now seen as being low grade substitutes for the 'real' thing - freshly ground coffee and fresh chicken meat.

Whether neutrally marinated meat will meet the same fate will depend on how its conceptual indefiniteness is settled. In the end, if the meat is considered to be a 'cheap' and somewhat 'dubious' alternative to 'real' meat, it is likely that neutrally marinated meat will neither be conceptually nor practically appropriated by consumers in the long run. In that case, it is likely that neutrally marinated meat will find its place in the catering market and perhaps in a small niche in the discount market.

\section{References}

Abildgaard, I. (2005), ["The Danes don't want long-life milk"] "Danskerne vil ikke have langtidsholdbar mælk", Samvirke, 25 February 2010.

Bruhn, C. (2008), "Consumer acceptance of food innovations", Innovation: management, policy \& Practice, Vol. 10 No. 1, pp 91-96.

Carr, M. et al. (2004), "Consumer acceptance of calcium-chloride-marinated top loin steaks", J ournal of Animal Science, Vol. 82 No. 5, pp 1471-1474. 
Crabtree, B. and Miller, W.L. (1999), "Using Codes and Code Manuals: A Template Organizing Style of Interpretation" in Crabtree, B. \& Miller, W.L. (Ed.), Doing Quality Research, Sage Publications.

Danish Meat Association (2006), ["Neutrally marinated beef demands new frying habits"] "Marineret oksekød kræver nye stegevaner", available at:

http://www. danishmeat.dk/Forside/publikationer/Ny_viden_om_s/2006/Nr__2/Marineret _oks.aspx (accessed 5 March 2009).

Dörffer, M. (2002), [Marination of meat - more than culinary variation?] Marinering af kød - mere end kulinarisk variation?, available at:

www.danishmeat.dk/Slagteri_og_Foraedling/Produktkvalit/Spisekvalitet/Publikatione r/Marinering_af.aspx (accessēed 5 March 2009).

Dörffer, M. (2003), [Neutrally marinated meat - a challenge to fresh meat?] Marineret kød - en udfordring til det ferske?, available at:

http: // www.danishmeat.dk/Slagteri_og_Foraedling/Backup/Produktkvalit/Spisekvalit et/Publikationer/Marineret_koe.aspx (accessed 5 March 2009).

Folketingets Lovsekretariat (2006), ["§ 20 question S 4152 about "natural marinated meat" "] "§ 20-spørgsmål S 4152 om "naurel marineret kød", available at:

http: //www. ft.dk/samling/20051/spoergsmaal/s4152/svar/249807/index.htm\#dok (accessed 20 October 2010).

Folketingets Lovsekretariat (2007), ["Food, Agriculture and Fisheries, normal part 20072008 2. sitting - Question 32, Danish Parliament"] "Udvalget for Fødevarer, Landbrug og Fiskeri, Alm. del 2007-2008 (2. samling): Spørgsmål og svar - Spørgsmål 32", available at:

http://www.ft.dk/dokumenter/tingdok.aspx?/Samling/20072/almdel/FLF/spm/32/index.h tm (accessed 20 October 2010).

Guldagger, M. (2010), ["Applause when the Danish Parliament slaughtered pumped chicken"] "Klapsalver da Folketinget slagtede pumpet kylling", Politikken, 4 J une 2010.

Hammersley, M. and Atkinson P. (1995). Ethnography, Routledge, London.

Haugaard, s. (2007), ["Arla expect to double sales of milk in Germany"] "Arla forventer fordobling af mælkesalg i Tyskland", available at:

http: // www. business.dk/foedevarer/arla-forventer-fordobling-af-maelkesalg-ityskland (accessed 16 September 2010).

Hayes, J. E. et al. (2006), "The effect of enhancement with salt, phosphate and milk proteins on the physical and sensory properties of pork loin", Meat Science, Vol. 72, pp 380-386.

Holm, L. and Kildevang, H. (1996), Consumers' views on food quality. A qualitative interview study. Appetite, Vol. 27 No. 1, pp 1-14.

Holm, L. and Møhl, M. (2000), The role of meat in everyday food culture: An analysis of an interview study in Copenhagen. Appetite, Vol. 34 No. 3, pp 277-284.

Hvilsom, F. (2006). ["Meat is being pumped with water"] "Kød bliver pumpet med vand", Politiken, 19 April 2006.

Jydske Vestkysten (2005), ["Watery chicken on the menu"] "Vandkylling på menuen", 23 May 2005. 
Korzen-Bohr, S. and O'Doherty Jensen, K. (2006), "Heart disease among postmenopausal women: Acceptability of functional foods as a preventive measure", Appetite, Vol. 46 No. 2, pp152-163.

Miller, D. (1987), Material culture and mass consumption, Basil Blackwell, Oxford.

Niva, M. (2008), Consumers and the conceptual and practical appropriation of functional foods, National Consumer Research Centre, Helsinki.

Pietrasik, Z. and Shand, P.J.(2011), "Effects of moisture enhancement, enzyme treatment, and blade tenderization on the processing characteristics and tenderness of beef semimembranosus steaks", Meat Science, Vol. 88 No. 2, pp 8-13.

Robbins, K. et al. (2003), "Consumer attitudes towards beef and acceptability of neutrally marinated beef", Meat Science, Vol. 65 No. 2, pp 721-729.

Søndergaard, M. (2007), ["Theme: Chicken"] "Tema: Kyllinger", Tænk, Vol. 80, pp 2633.

Tørngren, M. (2007), ["Eating Quality Experiment: Implications of produce quality, brine composition and injection gain for eating quality and robustness of marinated pork (phase 2)"] "Spisekvalitetsforsøg: Betydning af råvarekvalitet, lagesammensætning og sprøjtetilvækst for spisekvalitet og robusthed af marineret svinekød (Fase 2)", Rapport DW 45549, Slagteriernes Forskningsinstitut, Roskilde. 